\title{
Hatching Success of Koi Carp (Cyprinus carpio) Embryos Following Short-Term Storage of Unfertilized Eggs
}

\section{Yusuf BOZKURT}

İskenderun Technical University, Faculty of Marine Sciences and Technology, Department of Aquaculture, İskenderun, Hatay, Turkey.

Corresponding Author: yusuf.bozkurt@iste.edu.tr

Received 23 April 2019; Accepted 17 June 2019; Release date 15 December 2019.

How to Cite: Bozkurt, Y. (2019). Hatching success of koi carp (Cyprinus carpio) embryos following short-term storage of unfertilized eggs. Acta Aquatica Turcica, 15(4), 481-486. https://doi.org/10.22392/actaquatr.557364

\begin{abstract}
The present study was carried out to determine effect of different mediums and storage periods on fertilization and hatching success of koi carp (Cyprinus carpio) embryos following short-term storage of unfertilized eggs. The batches of about 200 pooled eggs treated with 20-ml three different artificial mediums (Cognie, Kurokura, Zhang-Liu) and ovarian fluid in 15-cm petri dishes, were stored at $20^{\circ} \mathrm{C}$ for 60,120 or $180 \mathrm{~min}$. Eggs were fertilized by adding $100 \mu \mathrm{l}$ sperm in each petri dishes at the end of the each storage periods. Although there were no statistically significant differences between groups, the highest mean fertilization rate was $68 \%$ and the incubation rate was $27 \%$ in egg samples stored in the Ovarian fluid for 60 minutes. Results obtained from this study indicate that Ovarian fluid is the most suitable solution for the short-term storage (60-180 min) of koi carp eggs.
\end{abstract}

Keywords: Cyprinus carpio, short-term preservation, egg, embryo

Döllenmemiş Yumurtaların Kısa Süreli Muhafazasını Takiben Koi Sazanı (Cyprinus carpio) Embriyolarının Kuluçkadan Çıkış Başarısı

Özet

Bu çalışma, farklı medyumların ve muhafaza sürelerinin, döllenmemiş yumurtaların kısa süreli muhafazasını takiben koi sazanı (Cyprinus carpio) embriyolarının kuluçkadan çıkış başarısını belirlemek amacıyla yürütülmüştür. 200 adetlik yumurta kümeleri 15 ml'lik petri kutuları içerisinde 20 ml'lik farklı medyumlarla (Cognie, Kurokura, Zhan-Liu) ve Ovaryum sıvısı ile muamele edilerek $20^{\circ} \mathrm{C}$ 'de 60,120 ve $180 \mathrm{dk}$ süre ile muhafaza edilmişlerdir. Her muhafaza süresinin sonunda, her petri kutusundaki yumurtalar $100 \mu \mathrm{l}$ sperma ile döllenmiştir. İstatiksel olarak gruplar arasında farkl1lık tespit edilmemekle birlikte, ovaryum sıvısında $60 \mathrm{dk}$ muhafaza edilen yumurta örneklerinde en yüksek ortalama fertilizasyon \%68; kuluçka çıkış oranı ise \%27 olarak belirlenmiştir. Bu çalışmadan elde sonuçlar, koi sazanı yumurtalarının 60-180 dk muhafaza edilmesinde en uygun sulandırıcının Ovaryum sıvısı olduğunu göstermiştir.

Anahtar kelimeler: Cyprinus carpio, kısa süreli muhafaza, yumurta, embriyo

\section{INTRODUCTION}

In spite of cryopreservation of sperm has been widely investigated for many fish species, application of the same method for the fish eggs has not yet developed with favorable results because of its large size, high water content, the mass of yolk and the permeability properties of membranes (Lubzens et al., 2005). Thus, short-term preservation protocols applying positive temperatures have been developing for the female gametes.

Short-term preservation aims increasing of post-spawning gamete longevity, improving of hatchery management and minimizing of the problems resulting from inbreeding (Bromage and Roberts, 1995). Additionally, short-term preservation is rather useful and advantageous in various hatchery operations. For instance, it is frequently applied in short-distance transportations of female gametes during artificial propagation and in chromosome-set manipulations (Stoss, 1983). 
On the other hand, the period for the artificial fertilization of fish eggs is limited under hatchery conditions because of continious reduction of their quality with time. The ovulated eggs should be fertilized within a certain period following the ovulation process in order to obtain viable embryos (Hobby and Pankhurst, 1997). Because, fertility of ovulated eggs progressively decreases and then disappears when they are kept in body cavity of the female for a long time. So, prolonging of the egg viability becomes more critical in terms of fertilization success following their releasing from the gonads. From this point of view, establishing of a protocol is an important issue for the conservation of unfertilized eggs in terms of commercial aquaculture and biological conservation programs.

It is well known that there is lack of information regarding in vitro preservation of koi carp eggs in different artificial mediums. Therefore, the purpose of the present study was to explore effect of different storage periods and artificial mediums on fertility and hatching success of ornamental koi carp (Cyprinus carpio) eggs under in vitro conditions.

\section{MATERIAL and METHODS}

\section{Broodstock management and collection of gametes}

Mature koi carp broodfish was collected from soil ponds by seining and transported into the hatchery. Female (10) and male (4) broodfish were held separetely in holding tanks supported with a water flow of $2.5 \mathrm{l} / \mathrm{min}$ at $24^{\circ} \mathrm{C}$ containing $6-7 \mathrm{mg} / 1 \mathrm{O}_{2}$ in the hatchery.

Females have large and soft abdomen, red urogenital papilla and males releasing sperm with slight abdominal pressure were assumed to be ready for the hormone treatment. Commercially available carp pituitary extract (CPE) was used as spawning agent. In order to induce to spawning, CPE in Ringer solution was applied intramuscularly to the females in two portions as the priming and releasing doses $(0.5$ and $2.0 \mathrm{mg} / \mathrm{kg}$ body weight respectively) with a $14-\mathrm{h}$ interval between doses. Males received a single dose of CPE $(1.0 \mathrm{mg} / \mathrm{kg}$ body weight $)$ intramuscularly at the time of the second dose was applied to the females.

$100 \mathrm{mg} / \mathrm{l}$ quinaldine sulfate was applied to the broodfish for anesthetization and stripped via gentle abdominal massage. Eggs, ovarian fluid and sperm were collected separately from each female and male broodfish. Contamination of gametes with urine, mucus, blood or feces was avoided during collection of gametes. The ovarian fluid was separated by pouring the eggs onto a screen suspended over a plate and purified. Following colection, this fluid was used for storage purposes. Sperm samples collected from four males into 50 -ml glass beakers, were checked in term of motility before fertilization. For this aim, $10 \mu \mathrm{l}$ drop of sperm was placed on a microscope slide and $20 \mu \mathrm{l}$ distilled water were added. Then, sperm suspension was thoroughly mixed for $3 \mathrm{~s}$. The motility and motility duration of spermatozoa were immediately recorded for $1 \mathrm{~min}$ following activation using a CCD video camera (CMEX-5, the Netherlands) mounted on a phase-contrast microscope (100 x, Olympus BX43, Tokyo, Japan). Sperm motility was evaluated from sperm performing progressive forward movement. Samples showing more than $80 \%$ motility, were pooled in a $100-\mathrm{ml}$ glass beaker.

\section{Storage of eggs in artificial mediums and ovarian fluid}

Composition of three artificial mediums used for the in vitro storage of unfertilized koi carp eggs are shown in Table 1. The final $\mathrm{pH}$ of each medium was regulated according to the natural $\mathrm{pH}$ of the coelomic fluid of koi carp using $1.0 \mathrm{~N} \mathrm{HCl}$ and $1.0 \mathrm{~N} \mathrm{NaOH}$. In order to store eggs, a batch of 200 pooled eggs was gently placed in $15-\mathrm{cm}$ diameter petri dishes. The batches of eggs were washed with their storage mediums to eliminate coelomic fluid from the eggs. Petri dishes were filled with $20-\mathrm{ml}$ of their mediums and ovarian fluids and then in vitro stored for durations of 60, 120 and $180 \mathrm{~min}$ prior to fertilization inside of sterile Laminar air flow cabinet at constant temperature of $20^{\circ} \mathrm{C}$. 
Table 1. Composition of the artificial mediums

\begin{tabular}{|c|c|c|}
\hline Artificial Mediums & Composition & Reference \\
\hline Cognie Solution & $\begin{array}{l}0.88 \mathrm{~g} \text { of } \mathrm{NaCl}, 1.12 \mathrm{~g} \mathrm{KCl} \text {, } \\
0.36 \mathrm{~g} \text { Tris, } 150 \mathrm{ml} \text { with } \\
\text { distilled } \mathrm{H}_{2} \mathrm{O}\end{array}$ & (Cognie et al., 1989) \\
\hline Kurokura Solution & $\begin{array}{l}0.75 \mathrm{~g} \mathrm{NaCl}^{0.02} \mathrm{~g} \mathrm{KCl}, 0.02 \\
\mathrm{~g} \mathrm{CaCl}_{2}, 0.02 \mathrm{~g} \mathrm{NaHCO} \\
\text { ml distilled } \mathrm{H}_{2} \mathrm{O}\end{array}$ & (Kurokura et al., 1984) \\
\hline Zhang-Liu Solution & $\begin{array}{l}6 \mathrm{~g} \text { glucose, } 0.3 \mathrm{~g} \mathrm{NaCl}, 0.05 \mathrm{~g} \\
\mathrm{NaHCO}_{3} 100 \mathrm{ml} \text { distilled } \mathrm{H}_{2} 0\end{array}$ & (Zhang and Liu, 1991) \\
\hline Ovarian Fluid & $\begin{array}{l}2.58 \mathrm{mM} \mathrm{Mg}^{2+} 6.38 \mathrm{mM} \mathrm{Ca}^{2+} \text {, } \\
0.35 \mathrm{mM} \mathrm{Zn}^{2+}\end{array}$ & (Linhart et al., 1995) \\
\hline
\end{tabular}

\section{Fertilization and Hatching}

Following 60, 120 and 180 min storage periods of unfertilized eggs, the artificial mediums and ovarian fluids were removed from the petri dishes. Then, $100 \mu \mathrm{l}$ sperm showing motility higher than $80 \%$ and containing roughly $2 \times 10^{5} \mathrm{spz}$. was added on to the eggs for the fertilization. Fertilization process was performed in $500 \mathrm{ml}$ plastic containers using activation solution containing $3 \mathrm{~g}$ urea and 4 $\mathrm{g} \mathrm{NaCl}$ in 11 distilled water at $24^{\circ} \mathrm{C}$ for five minute through slow mixing of the eggs and sperm for 30 min. Then, eggs were washed with water in order to eliminate adhesiveness and gently transferred to the labelled Zuger glass incubators with running water $\left(24^{\circ} \mathrm{C}\right)$ where kept until eyeing $(14-16 \mathrm{~h})$ and hatching (3-4 d). Batches of eggs fertilized at time of " 0 " served as control group. Fertilization yield was determined at gastrulation stage. Dead embryos in partially or completely opaque eggs were removed during this period. The hatching rate was defined as the number of hatched eggs divided by the initial number of eggs used for fertilization. Newly hatched larvaes were removed by siphoning and counted. Each treatment was performed in triplicate for each artificial medium and storage period.

\section{Statistical analysis}

Results are presented as means \pm SE. Differences between treatment groups were analyzed by repeated analysis of variance (ANOVA). Significant means were subjected to a multiple comparison test (Duncan) for post-hoc comparisons at level of $\alpha=0.05$. All analyses were carried out using SPSS 17 for Windows Satistical Software Package.

\section{RESULTS}

Mean fertilization results regarding treatment groups were $64.60 \pm 4.50 \%, 44.60 \pm 8.08 \%$, $24.60 \pm 8.08 \%$ for the Cognie solution, $59.60 \pm 4.04 \%, 40.30 \pm 5.14 \%, 21.60 \pm 7.09 \%$ for the Kurokura solution and $48.30 \pm 7.37 \%, 37.60 \pm 5.14 \%, 17.6 \pm 7.09 \%$ for the Zhang Liu solution respectively following 60, 120 and 180 min storage periods. On the other hand, the highest overall meaning of fertilization results were obtained as $68.00 \pm 5.29 \%, 49.60 \pm 7.09 \%$ and $29.60 \pm 7.09 \%$ with ovarian fluid respectively for 60, 120 and 180 min storage periods (Figure 1). Differences between mean fertilization rates within the same medium group were significant $(p<0.05)$ when duration was considered. 


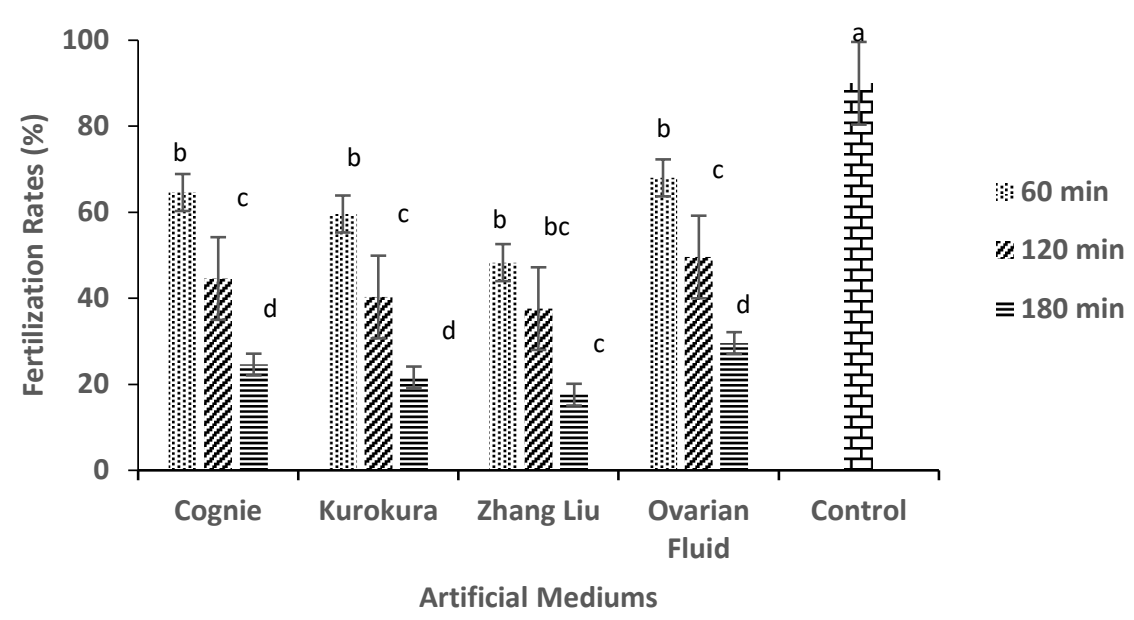

Figure 1. Fertilization rates of scaly carp eggs in vitro incubated in four different mediums for 0 (control), 60,120 and 180 min prior to fertilization.

Mean hatching results regarding treatment groups were $18.33 \pm 2.89 \%, 10.00 \pm 2.00 \%, 5.00 \pm 1.00 \%$ for the Cognie solution, $12.34 \pm 2.52 \%, 7.00 \pm 1.00 \%, 0 \%$ for the Kurokura solution and $7.34 \pm 2.52 \%$, $3.67 \pm 1.52 \%, 0 \%$ for the Zhang Liu solution respectively following 60,120 and $180 \mathrm{~min}$ storage periods. On the other hand, the overall meaning of the hatchings $(27.00 \pm 8.54 \%, 12.34 \pm 2.52 \%$ and $7.00 \pm$ $1.00 \%$ ) were also obtained as highest with the ovarian fluid respectively for 60, 120 and 180 min storage periods (Figure 2). It is interesting to note that there was no hatching with the Kurokura and Zhang-Liu artificial mediums for 180 min storage. Differences between mean hatching rates within the same medium group were significant $(p<0.05)$ when duration was considered.

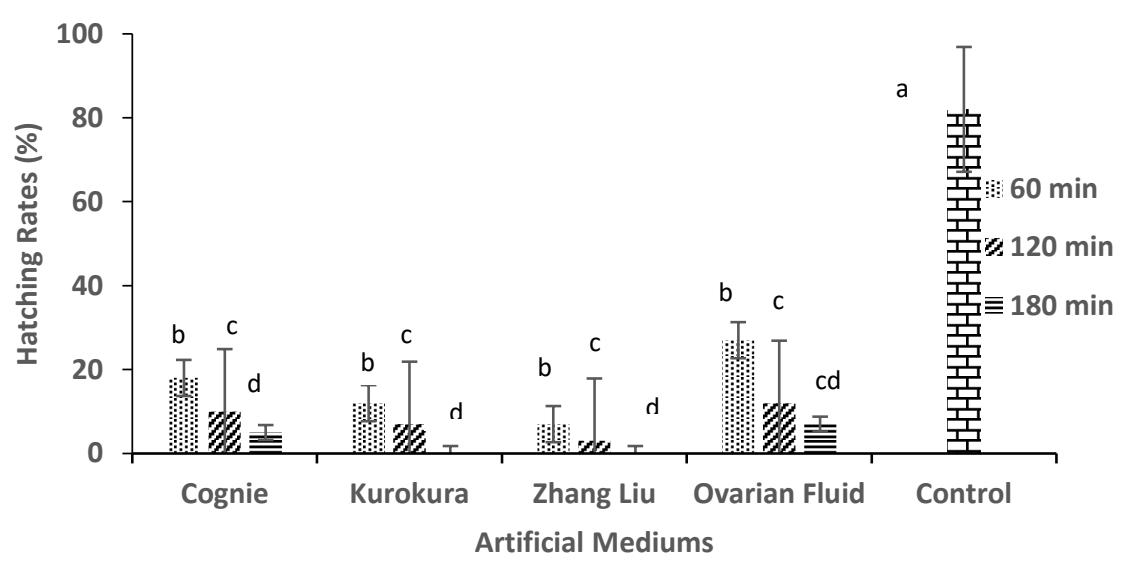

Figure 2. Hatching rates of scaly carp eggs in vitro incubated in four different mediums for 0 (control), 60, 120 and 180 min prior to fertilization.

\section{DISCUSSION}

Cryopreservation of fish eggs have been unsuccessful so far because of some difficulties such as removal of intercellular water during cooling, toxicity of cryoprotectants and also inhomogeneous freezing and thawing rates (Guan et al., 2008). Therefore, in vitro storage of unfertilized eggs seem the only alternative way instead of cryopreservation.

Some researchers have explored the development of eggs from fertility to eyeing stage (Lahnsteiner and Weismann, 1999; Goetz and Coffman, 2000). It is well known that less attention has been given to the survival of embryos from eyeing to the hatching stage following storage in different mediums for longer periods prior to fertilization. 
Rothbard et al. (1996) reported that common carp (Cyprinus carpio) eggs can be stored for $6 \mathrm{~h}$ at temperature range of $20^{\circ} \mathrm{C}-24.5^{\circ} \mathrm{C}$ maintaining their viability and fertility. Zlabek and Linhart (1987) compared in vitro storage of common carp (Cyprinus carpio), grass carp (Ctenopharyngodon idella) and silver carp (Hypophthalmichthys molitrix) eggs at two temperature regimes $\left(3^{\circ} \mathrm{C}-5 \mathrm{C}^{\circ}\right.$ and $14.5^{\circ} \mathrm{C}$ $18.0^{\circ} \mathrm{C}$ ) and reported that common carp eggs exhibited better fertility and survivality of embryos than those of the Chinese carps.

On the other hand, Takano et al. (1973) reported that storing of salmonid eggs as in vitro in artificial mediums less effective for similar periods. According to Takano et al. (1973), chum salmon eggs could be stored for only one day in a physiological saline. It is interesting to note that Erdahl et al. (1987) indicated the possibility of short-term $(5-10 \mathrm{~min})$ storage of unfertilized rainbow trout eggs in physiological saline solution without loss of fertility. In another study using common carp eggs (Bercsenyi et al., 1998) and no artificial medium, a decrease in temperature had a negative effect on fertilization capacity and hatch through time. Withler (1980) reported that eggs of common carp were stored undiluted in a preliminary study at $2^{\circ} \mathrm{C}$ to $9^{\circ} \mathrm{C}$ yielding no fertilization. In addition, Leung and Jamieson (1991) reported that fish eggs stored at refrigerated temperatures have been reducing their fertilizing potential due to cold shock.

From this point of view, in order to overcome cold shock effect of low temperature, koi carp eggs incubated moderately higher temperature $\left(20^{\circ} \mathrm{C}\right)$. It is known that mature eggs can be kept for several days in Ovarian fluid and the storage duration is related to the holding temperature (Bozkurt and Yavaş, 2012; Samarin et al., 2017; Ginatullina et al., 2018). The results of the present study demonstrated that all artificial mediums and ovarian fluid preserved koi carp eggs up to $180 \mathrm{~min}$ at relatively high temperature $\left(20^{\circ} \mathrm{C}\right)$ under in vitro conditions. On the other hand, Cognie solution exhibited higher fertilization capacity in all cases following Ovarian fluid. This shows that Cognie solution can be used with koi carp eggs to prolong fertilizing ability.

Short-term storage of koi carp eggs offers benefits for research and breeding. For instance, eggs from different stocks (from disease-free environments) could be transported among local hatcheries. In addition, koi carp could serve as a model for other warmwater species because of their hardiness and fecundity in captivity to study the fertilizing potential of stored eggs.

This study shows that eggs can be stored in an extender at $20^{\circ} \mathrm{C}$ for as long as $180 \mathrm{~min}$ with a loss of fertilization capacity compared to fresh eggs. It is obvious that there is an decrease in terms of fertility and hatchability of the eggs depending on period especially following $60 \mathrm{~min}$ storage in all cases. The decrease in fertilization and hatching rates during in vitro storage can be attributed to the composition of the artificial mediums, timing of ovulation, gamete quality, storrage temperature and condition of the recirculating water.

It should be known that the overall success of the conservation is highly depend on the extender composition, origin of the broodfish and egg batch. Additionally, preservation of metabolic activity and maintaining of viability of the eggs may be related to the health of the brood female, time of ovulation, incubation temperature and also quality of hatchery water (Linhart and Billard, 1995). From this point of view, the results of the current study showed that the survival of eggs in various treatments strongly depends on handling and management of spawners, temperature and egg quality prior to fertilization. On the other hand, future studies should address the specific conditions such as using of antibiotics in order to prevent bacterial infection and prolong storage period under in vitro conditions.

Acknowledgements: The author would like to thank the staff of State Hydraulic Works Fish Production Station for their technical assistance in Adana, Turkey.

\section{REFERENCES}

Bercsenyi, M., Magyary, I., Urbanyi, B., Orban, L., \& Horvath L. (1998). Hatching out goldfish from common carp eggs: interspecific androgenesis between two cyprinid species. Genome 41, 573-579.

Bozkurt, Y., \& Yavaş İ. (2012). Effect of temperatures and storage periods on fertilizing capacity of short-term preserved scaly carp (Cyprinus carpio) eggs. The Israeli Journal of Aquaculture-Bamidgeh, 64, 680-685.

Bromage, N.R., \& Roberts, R.J. (1995). Preservation of gametes. In: Bromage NR, Roberts RJ (Eds.), Broodstock Management and Egg and Larval Quality. Blackwell, Oxford. pp. 53-75.

Erdahl, A.W., Cloud, J.G., \& Graham, E.F. (1987). Fertility of rainbow trout (Salmo gairdneri) gametes: gamete viability in artificial media. Aquaculture, 60, 323-332. 
Ginatullina, E., Komrakova, M., \& Holtz, W. (2018). Chilled storage of unfertilized and fertilized rainbow trout (Oncorhynchus mykiss) eggs in sealed polyethylene bags at different temperatures. Aquaculture, 484, $214-$ 218.

Goetz, F.W., \& Coffman, M.A. (2000). Storage of unfertilized eggs of rainbow trout (Oncorhynchus mykiss) in artificial media. Aquaculture, 184 (3-4), 267-276.

Guan, M., Rawson, D.M., \& Zhang, T. (2008). Cryopreservation of zebrafish (Danio rerio) oocytes using improved controlled slow cooling protocols. Cryobiology, 56 (3), 204-208.

Hobby, A.C., \& Pankhurst, N.W. (1997). Post-ovulatory egg viability in the snapper Pagrus auratus (Sparidae). Marine and Freshwater Research, 48, 385-389.

Kurokura, H., Hirano, R., Tomita, M., \& Iwahashi, M. (1984). Cryopreservation of carp sperm. Aquaculture, 37 , 267-273.

Lahnsteiner, F., \& Weismann T. (1999). Changes in eggs of brown trout, rainbow trout and grayling during shortterm storage. North American Journal of Aquaculture, 61(3), 213-219.

Leung, L.K., \& Jamieson, B.G.M. (1991). Live preservation of fish gametes. pp. 245- 269. In Jamieson B. G. M. Fish Evolution and Systematics: Evidence from Spermatozoa. Cambridge Univ. Press, Cambridge.

Linhart, O., \& Billard, R. (1995). Biology of gametes and artificial reproduction in common tench (Tinca tinca L.). A review. Polish Archieves of Hydrobiology, 42, 37-56.

Lubzens, Z., Rosenfeld, H., Meiri, I., Olsson, P.E., Cerda, G., Babin, P.J., Admon, A., Carnervali, O., Rawson, D., Zhang, T., Dichtl, M., \& Pagelson, G. (2005). Cryopreservation of fish oocytes: achievements and prospects. In: van Stappen H, Sorgeloos W (Eds.). Larvi 05 - Fish \& Shellfish larviculture Symposium, European Aquaculture Society, Special Publication, 36, 296-297.

Rothbard, S., Rubinsthein, I., \& Gelman, E. (1996). Storage of common carp (Cyprinus carpio L.) eggs for short durations. Aquaculture Research, 27, 175-181.

Samarin, A.M., Żarski, D., Palińska-Żarska, K., Krejszeff, S., Blecha, M., Kucharczyk, D., \& Policar, T. (2017). In vitro storage of unfertilized eggs of the Eurasian perch and its effect on egg viability rates and the occurrence of larval malformations. Animal, 11(1), 78-83.

Stoss, J. (1983). Fish gamete preservation and spermatozoa physiology. In: Fish Physiology (eds. W.S. Hoar, D.J. Randall and E.M. Donaldson). Vol. IX B. Academic Press, New York: 305-350.

Takano, K., Hiroi, O., Yasukawa, M., \& Shetake, T. (1973). Studies on the retention of gametes of salmonids fishes. I - On the fertility of chum salmon eggs after storage. Scientific Reports of the Hokkaido Salmon Hatchery, 27, 31-37.

Withler, F.C. (1980). Chilled and cryogenic storage of gametes of Thai Carps and Cat Fishes. Canadian Technical Report of Fisheries and Aquatic Sciences, 948, 1-15.

Zhang, X., \& Liu, Y. (1991). Study of cryopreservation of fish spermatozoa. Acta Scientiarum Naturalium Universitatis Normalis Hunanensis, 14, 255-259.

Zlabek, A., \& Linhart, O. (1987). Short-term storage of non-seminated and unfertilized eggs of the common carp, grass carp and silver carp. Bulletin VURH Vodnany, 23, 3-11. 